\title{
The barley $\alpha$-thionin promoter is rich in negative regulatory motifs and directs tissue-specific expression of a reporter gene in tobacco
}

\author{
José A. Fernández, Manuel Moreno, María J. Carmona, Atilio Castagnaro \\ and Francisco García-Olmedo \\ Laboratorio de Bioquímica y Biología Molecular, E.T.S. Ingenieros Agrónomos-UPM, Madrid (Spain)
}

Key words: Negative regulatory element; Promoter analysis; Thionin; Tissue-specificity

The promoter of the barley $\alpha$-thionin gene $(1.6 \mathrm{~kb}$ ) fused to the $\beta$-glucuronidase (GUS) gene directs temporally-controled, tissue-specific expression in the endosperm of transgenic tobacco. The nucleotide sequence of this promoter shows negative regulatory motifs which have been functionally analyzed in other genes.

Thionins are cysteine-rich $5 \mathrm{kDa}$ plant polypeptides that have been identified in a limited number of wideranging taxa and are toxic to plant pathogens (see Refs. 1,2 for reviews). Known thionin sequences have been classified into five structural types, three of which are found in wheat and barley (I,II,V), where types I and $V$ are very abundant in endosperm and type II in leaves [2]. Genes encoding type I [3-5] and type V [6] are expressed during the cell-proliferation phase of endosperm development (first half), while those of type II are expressed in ethiolated leaves and induced under certain stress conditions, including infection by pathogens [7-9]. While the number of type II genes has been estimated at $10-100$ copies per haploid genome [7,9], only 1-2 copies per haploid genome seem to be present for the other two types $[5,6,10]$. This implies that high accumulation of thionins, which occurs to a similar extent in both cases, is achieved by the number of gene copies in the first case and by strong promoters in the second.

We have now sequenced the promoter of the $\alpha$ thionin gene from barley (type I) and have-found that this promoter directs tissue-specific, temporally-con- trolled expression of the $\beta$-glucuronidase (GUS) reporter gene in transgenic tobacco.

A DNA fragment ( $X b a \mathrm{I}-\mathrm{NcoI} ;-1.6 \mathrm{~kb}$ to $+45 \mathrm{~b}$ ) upstream of the coding region of the barley $\alpha$-thionin [5] was subcloned and both strands completely sequenced, using standard protocols for the dideoxy chain termination method. The sequence is shown in Fig. 1 and the main putative regulatory features are summarized in Table $J$. The nucleotide sequence contains several motifs that are identical or very similar to sequences that have been functionally characterized as negative regulatory elements in other plant genes.

A gene fusion involving the $\alpha$-thionin promoter and the bacterial $\beta$-glucuronidase (GUS) reporter gene was carried out as indicated in Fig. 2A. This gene construction ( $\alpha$-TH-GUS) was introduced and expressed in tobacco using the Bin19 binary vector system [11]. Non-transformed tobacco and transformants carrying a CaMV-35S-GUS fusion (hereafter 35S) were used as negative and positive controls, respectively.

GUS activity was measured fluorimetrically [12] in seeds, leaves, stems, and roots from individual regenerants and the data are summarized in Fig. 2B. Expression levels well above those of the $35 \mathrm{~S}$ positive control were observed in seeds, while only background fluorescence was observed in the other parts of the plant analyzed. Developing seeds were collected at different days after pollination and endosperms were separated from embryos and coats by hand dissection. GUS activity in $\alpha$-TH-GUS seeds was restricted of the en- 


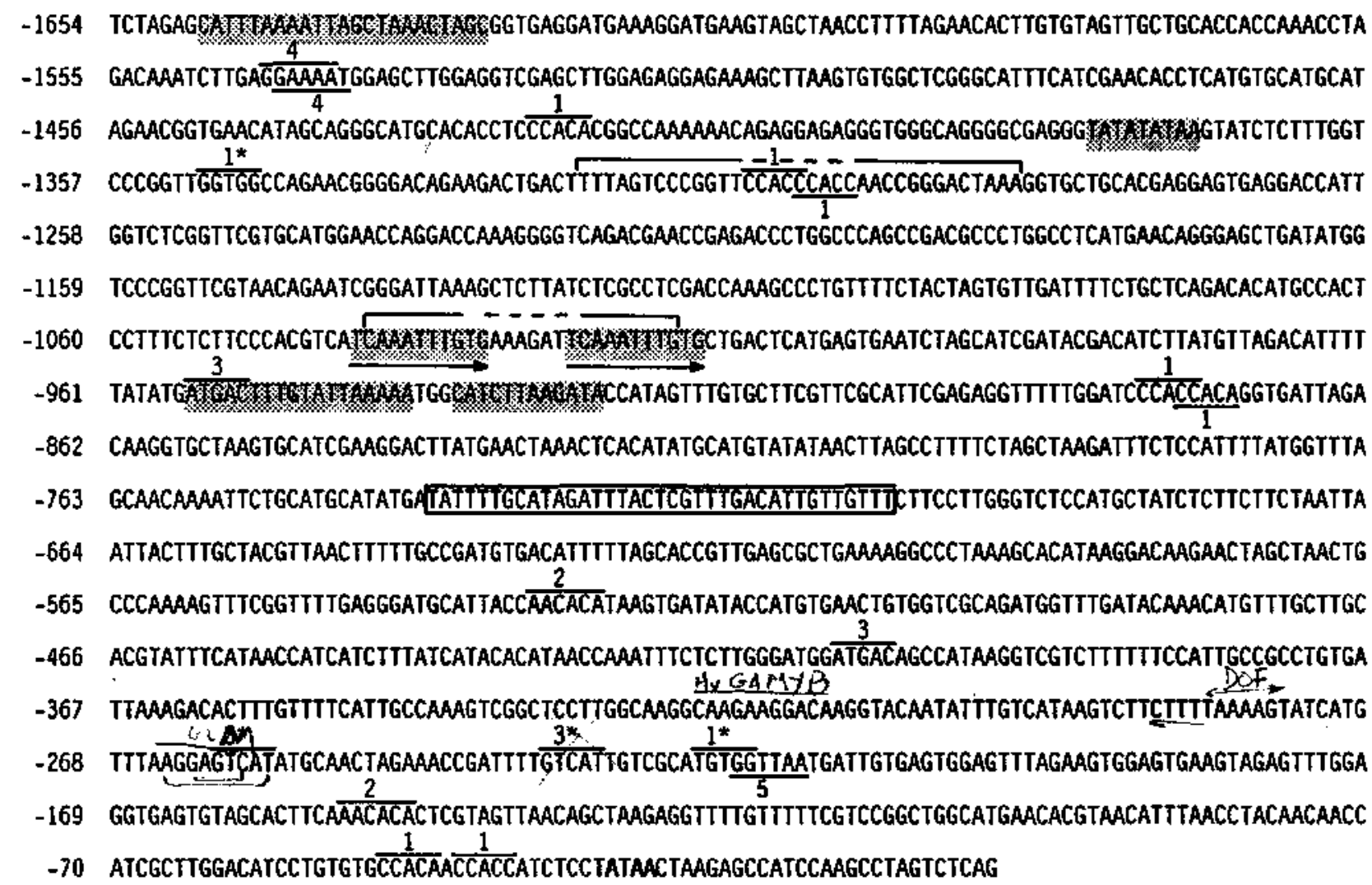

Fig. 1. Nucleotide sequence of the $\alpha$-thionin promoter from barley. Boxes with high homology to silencer motifs in other plant promoters are shadowed (see Table I). The following motifs are numbered and over or underlined (stars indicate complementary strands): $\beta$-phaseolin positive elements $\mathrm{CCACC} / \mathrm{A}(1)$ and AACACA(2); yeast GCN4 binding site ATGAC(3); consensus of boxes II and III of rbcS-3A GPuT/AAT/A(4) and box-II core of the same gene GGTTAA (5). A 10 bp direct repeat is indicated by arrows and two hairpin loops by an interrupted overline. A region with homology to Drosophila ORF-1 promoter is boxed and the putative TATA box is bold.

TABLE I

Summary of putative regulatory motifs in the $\alpha$-thionin promoter

\begin{tabular}{|c|c|c|c|}
\hline$\overline{\alpha-T h i o n i n ~ p r o m o t e r ~}$ & Other plant promoters & & Ref. \\
\hline $\begin{array}{l}\text { TATATATAAA }(-1379,-1371 \mathrm{bp}) \\
\text { CATCTTAAGATA }(-934,-923 \mathrm{bp}) \\
\text { TCAAATTTGTG }(-1040,-1020 \mathrm{bp}) \\
\qquad \begin{array}{r}(-1022,-1012 \mathrm{bp}) \\
\text { ATGACTTTGTATTAAAAA }(-965,-938 \mathrm{bp})\end{array} \\
\text { CATTTAAAATTAGCTAAACTAGC }(-1646,-1623 \mathrm{bp})\end{array}$ & $\begin{array}{l}\text { Silencer motifs } \\
\text { Cab identical }(-964 *,-972 * \text { bp) } \\
\qquad\left(-953^{*},-968 * \text { bp }\right) \\
\text { Cab similar }(-1067,-1057 \mathrm{bp}) \\
\text { rbcS-3A similar }(-160,-150 \mathrm{bp}) \\
\text { Cab similar }\left(-1059^{*},-1077^{*} \mathrm{bp}\right) \\
\text { rbcS-3A similar }\left(-104^{*},-121^{*} \mathrm{bp}\right) \\
\text { CHS } 15 \text { similar }(-289,-273 \mathrm{bp}) \\
\text { CHS } 15 \text { similar }(-321,-301 \mathrm{bp}) \\
\left(-211^{*},-237 * \mathrm{bp}\right)\end{array}$ & $\because$ & $\begin{array}{l}13 \\
13 \\
13 \\
14 \\
13 \\
14 \\
15 \\
15 \\
15\end{array}$ \\
\hline $\begin{array}{l}\text { CCACC / A ( } 9 \text { repeats in Fig. } 1) \\
\text { AACACA ( } 2 \text { repeats in Fig. 1) } \\
\text { ATGAC ( } 4 \text { repeats in Fig. 1) } \\
\text { GPUT /AAAT } / \text { A }(2 \text { repeats in Fig. 1) } \\
\text { GGTTAA }(-218,-213 \text { bp) }\end{array}$ & $\begin{array}{l}\text { Identity to other motifs } \\
\beta \text {-Phs pentamer box }(-468,-391 \mathrm{bp}) \\
\text { hexamer box }(-391,-295 \mathrm{bp}) \\
\text { binding consensus yeast GCN4 } \\
\text { rbcS-3A binding site consensus } \\
\text { box II core rcbS-3A }\end{array}$ & $\cdot$ & $\begin{array}{l}16 \\
16 \\
17 \\
14 \\
14\end{array}$ \\
\hline
\end{tabular}

* complementary strand. 
A
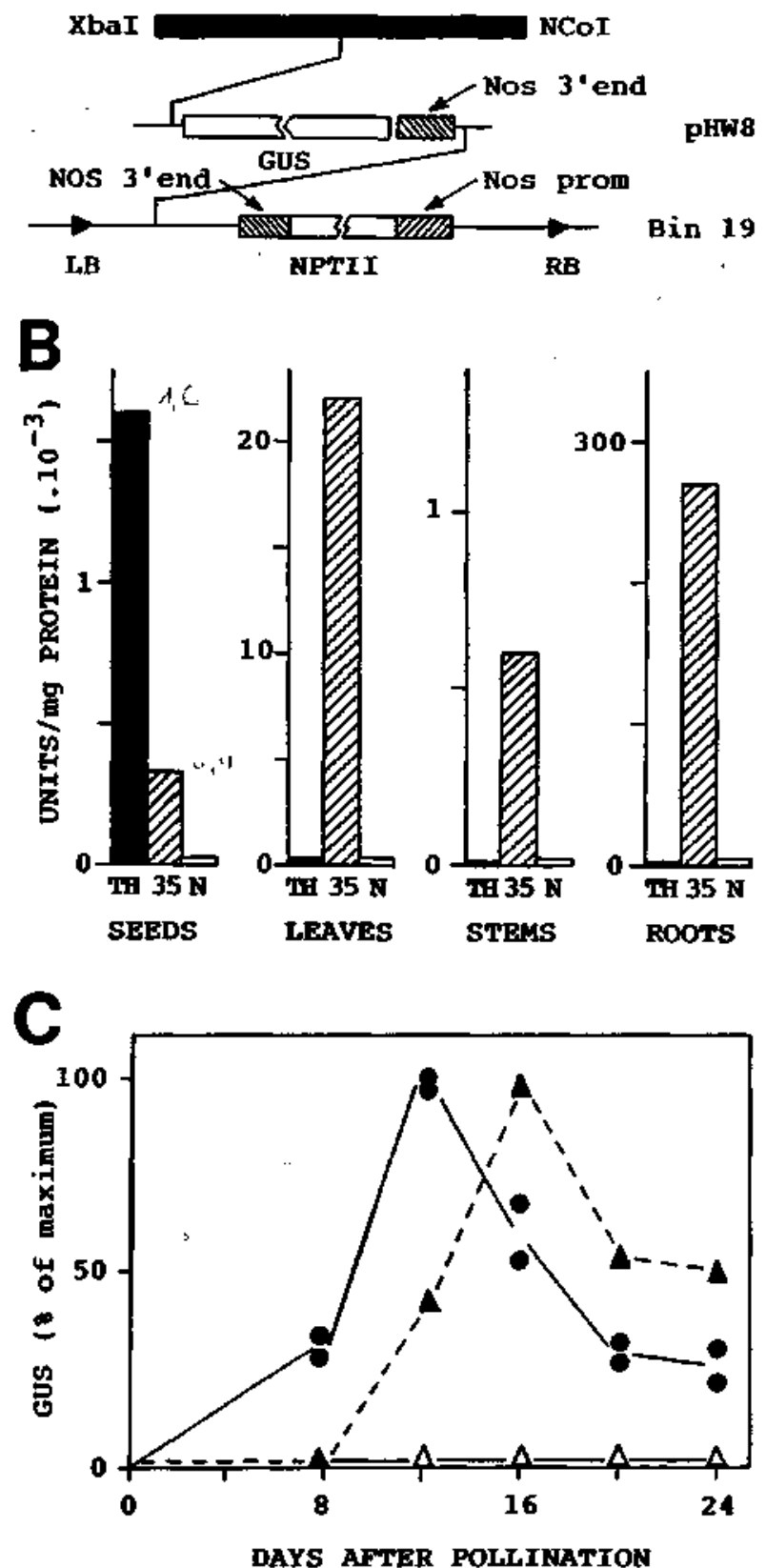

Fig. 2. Activity of the $\alpha$-thionin promoter fused to the $\beta$-glucuronidase (GUS) gene in transgenic tobacco. (A) Representation of the gene fusion inserted in the Bin19 vector. (B) GUS activity in different parts of tobacco transformants carrying the $\alpha$-TH-GUS construction (TH) and the CaMV-35S-GUS construction (35), and of nontransformed tobacco (N). Activity was determined fluorimetrically on a fresh weight basis [12] and protein was determined using the BCA kit (Pierce). Average yield of protein was $5.2 \mathrm{mg} / \mathrm{g}$ in seeds, $1.1 \mathrm{mg}$ in leaves, $2.8 \mathrm{mg} / \mathrm{g}$ in stems, and $2.2 \mathrm{mg} / \mathrm{g}$ in roots. 1 unit $-1 \mathrm{pmol}$ of 4-methylumbeliferome produced per min. (C) Temporal GUS expression in hand-dissected endosperms of $\alpha$-TH-GUS ( $\bullet$ ), 35SGUS $(\Delta)$ and non-transformed $(\Delta)$ tobacco plants. dosperm and reached a maximum at about 12 days after pollination, preceeding by about four days the peak of the $35 \mathrm{~S}$ control (Fig. 2C). This is in agreement with the expression of the $\alpha$-thionin gene in barley [5], which also takes place in the first half of the development period.

Technical assistance from D. Lamoneda and $\mathrm{J}$. García is acknowledged. Work was supported by a grant from the Fundación Ramón Areces.

\section{References}

1 García-Olmedo, F., Rodríguez-Palenzuela, P., Hernández-Lucas, C., Ponz, F., Maraña, C., Carmona, M.J., Lopez-Fando, J., Fernandez, J.A. and Carbonero, P. (1989) Plant Mol. Cell Biol. 6, $31-60$.

2 García-Olmedo, F., Carmona, M.J., López-Fando, J.J., Fernández, J.A., Castagnaro, A., Molina, A., Hernández- Lucas, C. and Carbonero, P. (1991) in Plant Gene Research Series: Genes Involved in Plant Defense (Boller, T.H. and Meins, F., eds.), pp. 283-302, Springer Verlag, Berlin.

3 Ponz, F., Paz-Ares, J., Hernández-Lucas, C., García-Olmedo, F. and Carbonero, P. (1986) Eur. J. Biochem. 156, 131-135.

4 Hernández-Lucas, C., Royo, J., Paz-Ares, J., Ponz, F., GarcíaOlmedo, F. and Carbonero, P. (1986) FEBS Lett. 200, 103-105.

5 Rodríguez-Palenzuela, P., Pintor-Toro, J.A., Carbonero, P. and García-Olmedo, F. (1988) Gene 70, 271-281.

6 Castagnaro, A., Maraña, C., Carbonero, P. and García-Olmedo, F. (1992) J. Mol. Biol. 224, 1003-1009.

7 Bohlmann, H. and Apel, K. (1987) Mol. Gen. Genet. 207, 446-454.

8 Bohlmann, H., Clausen, S., Behnke, S., Giese, H., Hiller, C., Reiman-Philipp, U., Schrader, G., Barkholt, V. and Apel, K. (1988) EMBO J. 7, 1559-1565.

9 Gausing, K. (1987) Planta 171, 241-246.

10 Fernández de Caleya, R., Hernández-Lucas, C., Carbonero, P. and García-Olmedo, F. (1976) Genetics 83, 687-699.

11 Bevan, M.W. (1984) Nucleic Acid. Res. 12, 8711-8721.

12 Jefferson, R.A. (1987) Plant Mol. Biol. Rep. 5, 387-405.

13 Castresana, C., García-Luque, 1., Alonso, E., Malik, V.S. and Cashmore, A.R. (1988) EMBO J. 7, 1929-1936.

14 Kuhlemeier, C., Fluhr, R., Green, P.J. and Chua, N.H. (1987) Genes Dev. 1, 247-255.

15 Lawton, M.A., Dean, S.M., Dron, M., Kooter, K.M., Kragh, K.M., Harrison, M.J., Yu, L., Tanguay, L., Dixon, R.A. and Lamb, C.J. (1991) Plant Mol. Biol. 16, 235-249.

16 Bustos, M., Begum, D., Kalkan, F.A., Battraw, M.J. and Hall, T.C. (1991) EMBO J. 10, 1469-1479.

17 Mark, S.T. and Richard, B.F. (1990) Plant Cel] 2, 1171-1180. 18 Templeton, N.S. and Potter, S.S. (1989) EMBO J. 8, 1887-1894. 